\title{
Antihyperglycemic and Lipid Profile Effects of Salvia amarissima Ortega on Streptozocin-Induced Type 2 Diabetic Mice
}

\author{
Jesus Ivan Solares-Pascasio ${ }^{1,2} \mathbb{D}$, Guillermo Ceballos ${ }^{2}$, Fernando Calzada ${ }^{1, *}$, Elizabeth Barbosa ${ }^{2}$ (D) \\ and Claudia Velazquez ${ }^{3}$
}

check for

updates

Citation: Solares-Pascasio, J.I.; Ceballos, G.; Calzada, F.; Barbosa, E.; Velazquez, C. Antihyperglycemic and Lipid Profile Effects of Salvia amarissima Ortega on StreptozocinInduced Type 2 Diabetic Mice. Molecules 2021, 26, 947. https:// doi.org/10.3390/molecules26040947

Academic Editors: Farid Chemat, Maurizio Battino,

Jesus Simal-Gandara and

Esra Capanoglu

Received: 13 December 2020

Accepted: 7 February 2021

Published: 11 February 2021

Publisher's Note: MDPI stays neutral with regard to jurisdictional claims in published maps and institutional affiliations.

Copyright: (c) 2021 by the authors. Licensee MDPI, Basel, Switzerland. This article is an open access article distributed under the terms and conditions of the Creative Commons Attribution (CC BY) license (https:/ / creativecommons.org/licenses/by/ $4.0 /)$.
1 Unidad de Investigación Médica en Farmacología, UMAE Hospital de Especialidades-2 ${ }^{\circ}$ Piso CORSE Centro Médico Nacional Siglo XXI, IMSS, Av. Cuauhtémoc 330, Col. Doctores, CP 06720 Ciudad de México, Mexico; jeivsp@gmail.com

2 Instituto Politécnico Nacional, Escuela Superior de Medicina, IPN, Salvador Díaz Mirón esq. Plan de San Luis S/N, Miguel Hidalgo, Casco de Santo Tomas, CP 11340 Ciudad de México, Mexico; gceballos@ipn.mx (G.C.); rbarbosa@ipn.mx (E.B.)

3 Área Académica de Farmacia, Instituto de Ciencias de la Salud, Universidad Autónoma del Estado de Hidalgo, Km 4.5, Carretera Pachuca-Tulancingo, Unidad Universitaria, CP 42076 Pachuca, Mexico; claudiav@uaeh.edu.mx

* Correspondence: fernando.calzada@imss.gob.mx; Tel.: +52-1-55-5627-6900 (ext. 21367)

Abstract: Salvia amarissima Ortega was evaluated to determinate its antihyperglycemic and lipid profile properties. Petroleum ether extract of fresh aerial parts of S. amarissima (PEfAPSa) and a secondary fraction (F6Sa) were evaluated to determine their antihyperglycemic activity in streptozocin-induced diabetic (STID) mice, in oral tolerance tests of sucrose, starch, and glucose (OSTT, OStTT, and OGTT, respectively), in terms of glycated hemoglobin (HbA1c), triglycerides (TG), and highdensity lipoprotein (HDL). In acute assays at doses of $50 \mathrm{mg} / \mathrm{kg}$ body weight (b.w.), PEfAPSa and F6Sa showed a reduction in hyperglycemia in STID mice, at the first and fifth hour after of treatment, respectively, and were comparable with acarbose. In the sub-chronic test, PEfAPSa and F6Sa showed a reduction of glycemia since the first week, and the effect was greater than that of the acarbose control group. In relation to $\mathrm{HbA1c}$, the treatments prevented the increase in $\mathrm{HbA} 1 \mathrm{c}$. In the case of TG and HDL, PEfAPSa and F6Sa showed a reduction in TG and an HDL increase from the second week. OSTT and OStTT showed that PEfAPSa and F6Sa significantly lowered the postprandial peak at $1 \mathrm{~h}$ after loading but only in sucrose or starch such as acarbose. The results suggest that S. amarissima activity may be mediated by the inhibition of disaccharide hydrolysis, which may be associated with an $\alpha$-glucosidase inhibitory effect.

Keywords: Salvia amarissima Ortega; diabetes mellitus; antihyperglycemic activity; lipid profile

\section{Introduction}

Diabetes mellitus (DM) type 2 is a complex chronic metabolic disease, characterized by hyperglycemia, and produced by a deficiency or loss of insulin activity; DM is generally accompanied by alterations like dyslipidemia, hypertension, obesity, or hyperinsulinemia [1-3]. According to estimates of the International Diabetes Federation (IDF), in 2019, more than 463 million people had DM (9.3\% of the global population) [1,2]. In terms of DM cases, Mexico is the sixth highest ranked country in the world (12.8 million case), and DM is the second highest cause of mortality [2,3]. Treatment of DM includes adoption of healthy habits and is accompanied by pharmacological therapy [2,4], including biguanides, sulfonylureas, glitazones, $\alpha$-glucosidase inhibitors, dipeptidyl peptidase-IV (DPP-IV) inhibitors, and incretin analogue therapies. The search for novel effective antidiabetic agents that avoid or reduce the side effects of these compounds is a continuous undertaking $[5,6]$.

The use of traditional medicine, based on medicinal plants or phytotherapy, particularly in developing countries, includes a large number of individual medicines and, in some 
cases, substitute allopathic treatments, because the latter are less economically accessible than medicinal plants [7]. In Mexico, it has been reported that approximately 383 plant species are used for treatment of DM; however, not all of these have been systematically studied to assess their clinical or preclinical efficacy [8].

Due to lack of information of medicinal plants, it is important to provide more information about Mexican flora and their use in traditional medicine due to their health implications, including their toxicity, and to establish if they are safe or effective. The information obtained in this study could be used to expand the knowledge and use of Salvia amarissima Ortega. Recent studies of potential antidiabetic plants were related to diverse mechanisms of how they generate antihyperglycemic activity, such as $\alpha$-glucosidase inhibitors, protein tyrosine phosphatase $1 \mathrm{~B}$ inhibitors (PTP-1B), insulin secretion, or inhibition of DPP-IV [9-20]. Rural populations use herbal products or combine them with allopathic treatments for the control of blood glucose levels [21,22]. These treatments include species such as Salvia amarissima Ortega (Syn. Salvia circinata Cav.), which is a perennial aromatic shrub native to Mexico, commonly known as "bretónica", "diabetina", "prodigiosa", "salvia", or "insulina", and used in Mexican traditional medicine for the treatment of ulcers, helminthiasis, and diabetes $[9,21,23,24]$. In previous studies, medium and high polarity extracts were isolated from $S$. amarissima: phenolic compounds (rosmarinic acid, rutin, pedalitin, apigenin-7-O- $\beta$-D-glucoside, 6-hydroxyluteoline, 2-(3-4-dimethoxyphenyl)-5-6dihydroxy-7-methoxy-4H-chromen-4-one, 5,6,4'-trihydroxy-7-3'-dimethoxyflavone, and isoquercitrin) and terpenoids (amarisolides $A-G$, amarissinines $A-C$, acetylamarisine B, teotihuacanin, $\alpha$-bourbanene, $\beta$-caryophyllene, $\delta$-elemene, $\alpha$-caryophyllene, $\beta$-selinene, germacrene $D$, and spathulenol $[14,15,24-26]$. Among these, amarisolide A, rutin, pedalitin, apigenin-7-O- $\beta$-D-glucoside, and 2-(3-4-dimethoxyphenyl)-5-6-dihydroxy-7-methoxy-4Hchromen-4-one are $\alpha$-glucosidase inhibitors. In addition, amarisolide A, rutin, rosmarinic acid, isoquercitrin, and pedalitin are protein-tyrosine phosphatase $1 \mathrm{~B}$ inhibitors (PTP1B) $[14,24]$. It is important to highlight that low polarity extracts of fresh aerial parts have not been studied; however, the study of non-polar compounds is scarce, including when they showed effects in pre-clinical sub-chronic studies $[9,15,24]$. The focused polarity of this study provides information for the selection of the best conditions for potential herbal preparations or pharmaceutical products obtained from S. amarissima.

The aim of this study was to evaluate the antihyperglycemic and lipid profile effects of the non-polar extract of Salvia amarissima and its active fraction in male normoglycemic and streptozocin-induced diabetes mellitus type 2 mice.

\section{Materials and Methods}

\subsection{General Information}

Methanol (CC: 904903), ethyl acetate (CC:10382681), and petroleum ether (CC: 8032324) solvents were purchased from J.T. Baker ${ }^{\mathrm{TM}}$ (Thermo Fisher Scientific, Waltham, MA, USA). Streptozocin (75\% $\alpha$-anomer basis, PN: S0130-5 G), nicotinamide (99.5\%, PN: 47865-U), glucose (anhydrous, PN: D9434-1 Kg), sucrose (99.5\% GC, PN: S9378-1 Kg), starch (CC 336155-1 Kg), acarbose (PN: PHR1253-500 mg), and canagliflozin (95\%, PN:721174-1 G) were obtained from Sigma-Aldrich ${ }^{\circledR}$ (Saint Louis, MO, USA). Silica gel (high purity grade (7734), pore size $60 \AA$, 70,230 mesh; CC: $391484-5 \mathrm{Kg}$ ) was purchased from Merck ${ }^{\circledR}$ (Merck ${ }^{\circledR}$, Darmstadt, Germany).

\subsection{Plant Material}

Salvia amarissima Ortega fresh aerial parts were collected in San Gregorio Atlapulco, Xochimilco, Mexico. The plant was identified by M.Sc. Santiago Xolalpa from the herbarium of the National Medical Center XXI Century, Mexican Institute of Social Security (IMSS) in México City, and a voucher specimen (16263) was made and deposited at the herbarium. 


\subsection{Obtaining the Petroleum Ether Extract of Salvia amarissima}

Fresh aerial parts of the plant were cut $(3 \mathrm{~kg})$ in small pieces and then all were added to $9 \mathrm{~L}$ of petroleum ether to perform a metabolite extraction by thorough maceration at room temperature for one week; this extraction process was performed twice [10]. At the completion, the extract was collected through filtration and concentrated at $40{ }^{\circ} \mathrm{C}$ in a rotary evaporator coupled to a vacuum system (Büchi Labortechnik AG, Flawil, Switzerland); the extract was named PEfAPSa (petroleum ether extract of fresh aerial parts of S. amarissima). The final dry weight of the extract was $8.01 \mathrm{~g}$ of yellow wax with a yield of $0.27 \%$.

\subsection{Column-Chromatography and Phytochemical Screening}

To better understand the activity of PEfAPSa, the dry extract was subjected to column chromatography using ethyl acetate (EtOAc) and methanol $(\mathrm{MeOH})$ solvent elution over silica gel $60 \mathrm{G}$, successively using $150 \mathrm{~mL}$ of petroleum ether-EtOAc (100:0 to 0:100) for each fraction, followed by a mixture of EtOAc-MeOH (90:10 to 50:50). As result, seven fractions were obtained, namely F1Sa, F2Sa, F3Sa, F4Sa, F5Sa, F6Sa, and F7Sa. Of these, based on the results of the acute assays of the fractions obtained, only Fraction 6 (F6Sa) was purified by preparative thin layer chromatography (TLC) silica gel 60F-254 (Merck), using a petroleum ether-acetone (85:15) mixture as the mobile phase to obtain the secondary metabolites. The process was repeated as needed with the remaining extract to obtain the largest number of fractions for in vivo experiments and preliminary analysis of pure compounds. Preliminary qualitative identification of pure compounds was conducted in terpene compounds and was performed by TLC using sulfuric acid (10\% in water) and/or ceric sulphate as revelators; pure compounds and terpenes standard had an Rf of 0.14 and were positive to ceric sulphate, indicating the presence of terpene compounds in F6Sa, but they were not yet characterized [27].

\subsection{Animal In Vivo Assays}

Male (for acute and sub-chronic assays, and oral tolerance tests (OTTs)) and female (for toxicity) Balb/c mice (20-25 g) were obtained from the animal bioterium of the National Medical Center XXI Century, Mexican Institute of Social Security (IMSS) in Mexico City, where animals were raised and maintained under standard laboratory conditions (conditions ( $12 \mathrm{~h} / 12 \mathrm{~h}$ light/dark cycles; temperature, $25 \pm 2{ }^{\circ} \mathrm{C}$; humidity $55-80 \%$ ) according to the Mexican Official Norm [10,28]. Food and water were provided ad libitum. The experimental protocol was registered and approved by the Local Research Committee with institutional register number FIS/IMSS/PROT/PRIO/19/110.

\subsection{Toxicity Test}

To determine if the PEfAPSa could be used safely, the acute toxic class method test 423 from the OECD [29] was performed. Fifteen Balb/c mice (only females), fasted overnight but allowed free access to water, were randomly assigned to the following groups of three mice each $(n=3)$ : (I) negative control only administered with distilled water, and also healthy mice administered with extract in a single dose at (II) $3 \mathrm{mg} / \mathrm{kg}$ b.w., (III) $30 \mathrm{mg} / \mathrm{kg}$ b.w., (IV) $300 \mathrm{mg} / \mathrm{kg}$ b.w., and (V) $3000 \mathrm{mg} / \mathrm{kg}$ b.w. Mice were not fed for $4 \mathrm{~h}$ after administration. Signs of toxic effects and/or lethality were observed in the first $6 \mathrm{~h}$ after single administration and then for $48 \mathrm{~h}$, and mice were examined for neurotoxic signs such as dizziness, lethargy, or aggressiveness. At the 0,2 , and $4 \mathrm{~h}$ mark after the load of the extract, glycemia was measured in all the treatment groups. The general health conditions of mice were observed daily for a period of 14 days for mortality, toxic effects, and/or changes in behavioral patterns. At the end of the experiment, the animals were sacrificed in a $\mathrm{CO}_{2}$ saturation chamber. Then, internal major organs (stomach, gut, kidney, spleen, 
and liver) were extracted, macroscopical observations were performed, and the relative organ weight was calculated [30,31] using the following formula:

$$
\text { Relative organ weight }=\frac{\text { Organ weight }(\mathrm{g})}{\text { Body weight of the animal on sacrifice day }(\mathrm{g})} \times 100
$$

\subsection{Nicotinamide-Streptozotocin-Induced Experimental Hyperglycemia in Mice}

Experimental hyperglycemia was induced in male Balb/c mice intraperitoneally by injection of streptozotocin (STZ) at a dose of $100 \mathrm{mg} / \mathrm{kg} \mathrm{b.w}$. dissolved in citrate buffer solution ( $\mathrm{pH} 4)$, which was maintained in ice prior to use. Fifteen minutes after the nicotinamide (NA) injection, intraperitoneal injection of nicotinamide at a dose of $240 \mathrm{mg} / \mathrm{kg}$ b.w. dissolved in distilled water were made in each male mouse at day zero. One week later, blood samples were taken from each animal, and those mice that showed blood glucose $\geq 210 \mathrm{mg} / \mathrm{dL}$ were considered as hyperglycemic and with experimental diabetes and were selected for the following studies [27].

\subsection{Acute Antihyperglycemic Assay}

To determine how PEfAPSa and F6Sa generate a diminution of glycemia, acute assays in diabetic animals were performed. Animals were divided into experimental groups of six animals each $(n=6)$, and treatments were administrated by the intragastric route with a cannula in a single administration divided into different groups of the following treatments: acarbose, PEfAPSa, and fractions 1-7 of S. amarissima. The quantities applied to the animal groups are listed below.

Acarbose acute activity: (I) streptozocin-induced diabetic (STID) mice control, (II) STID mice + acarbose $50 \mathrm{mg} / \mathrm{kg}$ b.w., and (III) STID mice + acarbose $100 \mathrm{mg} / \mathrm{kg}$ b.w. This was performed at the same time as the PEfAPSa assay.

Acute activity of PEfAPSa: (I) STID mice control, (II) STID mice + acarbose $100 \mathrm{mg} / \mathrm{kg}$ b.w. as drug control group, (III) STID mice + PEfAPSa $50 \mathrm{mg} / \mathrm{kg}$ b.w., (IV) STID mice + PEfAPSa $100 \mathrm{mg} / \mathrm{kg}$ b.w., and (V) STID mice + PEfAPSa $300 \mathrm{mg} / \mathrm{kg}$ b.w. This was performed at the same time as the acarbose assay.

Acute assay of fractions: (I) STID mice control, (II) STID mice + acarbose $100 \mathrm{mg} / \mathrm{kg}$ b.w., (III) STID mice + F1Sa 50 mg / kg b.w., (IV) STID mice + F2Sa 50 mg/kg b.w., (V) STID mice + F3Sa 50 mg/kg b.w., (VI) STID mice + F4Sa 50 mg/kg b.w., (VII) STID mice + F5Sa $50 \mathrm{mg} / \mathrm{kg}$ b.w., (VIII) STID mice + F6Sa 50mg $/ \mathrm{kg}$ b.w., and (IX) STID mice + F7Sa 50mg $/ \mathrm{kg}$ b.w.

Acute activity of F6Sa: (I) STID mice control, (II) STID mice + acarbose $100 \mathrm{mg} / \mathrm{kg}$ b.w., (III) STID mice + F6Sa 25 mg / kg b.w., (IV) STID mice + F6Sa 50 mg/kg b.w., (V) STID mice + F6Sa $100 \mathrm{mg} / \mathrm{kg}$ b.w.

The healthy mice group was administrated with vehicle (Tween $80: \mathrm{H}_{2} \mathrm{O}, 2: 98$ ). Blood samples were collected at $0,1,3,5$, and $7 \mathrm{~h}$ after the first administration of each treatment. These assays were performed at the same time $[10,27]$.

\subsection{Sub-Chronic Assay}

The sub-chronic assay was performed on diabetic mice to observe the behavior of the treatments, contrasting healthy and diabetic animals. Diabetic mice were divided into 4 experimental groups of six animals each $(n=6)$, and treatments were administrated daily by the intragastric route for six weeks as follows: (I) diabetic mice administered only with vehicle (Tween 80: $\mathrm{H}_{2} \mathrm{O}, 2: 98$ ), (II) PEfAPSa (50 mg/kg b.w.), (III) F6Sa (50 mg/kg b.w.), (IV) acarbose (100 mg/kg b.w.) as reference group, and (V) healthy group administered only with vehicle. Blood glucose levels $(\mathrm{mg} / \mathrm{dL})$ and body weight variations $(\mathrm{g})$ were evaluated every 7 days, and every 15 days, evaluations were made of glycated hemoglobin (HbA1c), triglycerides (TG), and high-density lipoprotein (HDL). HbA1c, TG, and HDL blood samples were obtained by puncture in the caudal vein to obtain blood samples. HbA1c was measured by Clover A1c Analyzer (Infopia Co., Ltd., Anyang, Korea) using 
$40 \mu \mathrm{L}$, and TG and HDL were measured with the lipid panel of Cardiocheck Professional PA Silver (Polymer Technology Systems, Whitestown, IN, USA) using $40 \mu \mathrm{L}$ of blood. At

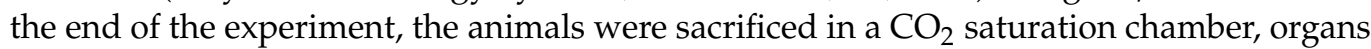
were macroscopically evaluated $[9,28]$, and the relative organ weight of each animal was calculated with the equation in Section $2.6[30,31]$.

\subsection{Oral Tolerance Test (OTT)}

To identify part of the probable mechanism by which the plant exerts its activity, inhibition of $\alpha$-glucosidases (with sucrose and starch) or the glucose transport mechanism (glucose), studies were conducted consistent with other plants species from diverse families, such as Calea ternifolia [9], Annona cherimolla [10], or Scutellaria baicalensis [11], for example, that had been studied as antihyperglycemic agents [8-13]. The OTT technique was performed after an overnight fasting $(18 \mathrm{~h})$ of normoglycemic mice. Mice were divided into groups of six animals each and administrated with the following treatments: (I) Tween 80: $\mathrm{H}_{2} \mathrm{O}$ (2:98), (II) PEfAPSa (50 mg/kg b.w.), (III) PEfAPSa (100 mg/kg b.w.), (IV) F6Sa (50 mg/kg b.w.), (V) F6Sa (100 mg/kg b.w.), (VI) acarbose (100 mg/kg b.w.) as control for oral sucrose tolerance test (OSTT) and oral starch tolerance test (OStTT), or (VII) canagliflozin $(100 \mathrm{mg} / \mathrm{kg})$ control for oral glucose tolerance test (OGTT). Baseline (time $0 \mathrm{~h}$ ) was set before the administration of the treatment previously described; after $30 \mathrm{~min}$, the respective treatment was administered to the mice as follows: glucose $(1.5 \mathrm{~g} / \mathrm{kg} \mathrm{b} . \mathrm{w}$.), sucrose $(3 \mathrm{~g} / \mathrm{kg}$ b.w.), and starch ( $3 \mathrm{~g} / \mathrm{kg}$ b.w.). Blood samples were collected at 1,2 , and $4 \mathrm{~h}$ after the glucose load $[9,27]$.

\subsection{Collection of Blood Glucose and Determination of Blood Glucose}

Blood samples for each assay were collected from the caudal vein by a small incision at the end of the tail, and the glucose levels $(\mathrm{mg} / \mathrm{dL})$ were measured using a commercial glucometer (Accu-chek Performa, Roche Diagnostics GmbH, Manheim, Germany).

\subsection{Statistical Analysis}

Data are expressed as the mean $( \pm)$ with the standard error of the mean (SEM). Statistical significance was determined by one-way analysis of variance (ANOVA) followed by the Dunnet test (GraphPad Prism Version 6.01; GraphPad Software Inc., La Jolla, CA, USA), with post hoc test $*$-values $<0.05$ indicating significant differences between experimental group means.

\section{Results}

\subsection{In Vivo Assays}

\subsubsection{Acute Oral Toxicity Test of the PEfAPSa}

The single administration of PEfAPSa at all tested dose in female mice by gavage did not induce lethality or behavior alterations, macroscopic tissue injury, or total weight loss (data not shown) during the 14 day observation period; therefore, the $\mathrm{LD}_{50}$ value of PEfAPSa was established as $>3000 \mathrm{mg} / \mathrm{kg}$ b.w. in female mice when administered by the oral route according to OECD 423 guidelines [28]. For our study, the parameter of importance was the glycemia of healthy mice at the doses established in the OECD guidelines. Table 1 shows the results obtained in which there was no hypoglycemia, that is, the principal secondary effect of the hypoglycemic drugs. At doses of 300 and $3000 \mathrm{mg} / \mathrm{kg}$ b.w., at the second hour of treatment an increase in glycemia was observed, before a return to the initial values. Because of the prevention of mortality, the therapeutic window and range of use were wide. 
Table 1. Glycemia measurements in the toxicity assay of PEfAPSa.

\begin{tabular}{|c|c|c|c|c|c|}
\hline \multirow[b]{2}{*}{ Time (h) } & \multicolumn{3}{|c|}{ Treatments } & \multirow[b]{2}{*}{$\begin{array}{c}\text { Healthy Mice + } \\
\text { PEfAPSa } \\
300 \text { mg/kg b.w. }\end{array}$} & \multirow[b]{2}{*}{$\begin{array}{c}\text { Healthy Mice + } \\
\text { PEfAPSa } \\
3000 \mathrm{mg} / \mathrm{kg} \mathrm{b.w.}\end{array}$} \\
\hline & Healthy Mice & $\begin{array}{c}\text { Healthy Mice + } \\
\text { PEfAPSa } 3 \mathrm{mg} / \mathrm{kg} \\
\text { b.w. }\end{array}$ & $\begin{array}{c}\text { Healthy Mice + } \\
\text { PEfAPSa } \\
30 \text { mg/kg b.w. }\end{array}$ & & \\
\hline 0 & $116.67 \pm 3.96$ & $119.33 \pm 2.00$ & $113.44 \pm 2.37$ & $108.78 \pm 1.51$ & $115.67 \pm 2.00$ \\
\hline 2 & $114.78 \pm 3.32$ & $115.33 \pm 2.62$ & $117.33 \pm 5.43$ & $129.11 \pm 3.19$ * & $151.56 \pm 1.79$ * \\
\hline 4 & $110.89 \pm 1.63$ & $109.67 \pm 1.23$ & $109.89 \pm 1.15$ & $112.89 \pm 2.75$ & $115.67 \pm 1.62$ \\
\hline
\end{tabular}

Toxicity of the PEfAPSa at doses of 3, 30,300, and $3000 \mathrm{mg} / \mathrm{kg}$ b.w. in healthy mice. ${ }^{*} p<0.05$ represents significantly different one-way ANOVA followed by Dunnet's post hoc test for comparison with respect to vehicle at the same time.

\subsubsection{Evaluation of Acute Antihyperglycemic Effect of PEfAPSa}

The acute antihyperglycemic activity was evaluated to determine the potential antihyperglycemic effect of PEfAPSa and to select the dose for the subsequent sub-chronic assay, which indicates the behavior of the PEfAPSa at different doses (Figure 1A). Furthermore, this assay was used to evaluate two doses of acarbose to determine that to be used as the drug control. The extract was evaluated at three single doses of 50,100, and $300 \mathrm{mg} / \mathrm{kg}$ b.w. Among these, two doses, namely 50 and $300 \mathrm{mg} / \mathrm{kg}$ b.w., generated a significant decrease in hyperglycemia in STID mice in all of the measured times. The effect was comparable to that obtained with acarbose at a dose of $100 \mathrm{mg} / \mathrm{kg}$ b.w. For subsequent studies, the dose of $50 \mathrm{mg} / \mathrm{kg}$ b.w. of PEfAPSa was selected, considering it is a lower dose with major and constant effects with time. In contrast, those diabetic mice that were administered with PEfAPSa at a dose of $100 \mathrm{mg} / \mathrm{kg}$ b.w. showed increased levels of blood glucose compared even to those results obtained from the group of diabetic mice without treatment $(375 \mathrm{mg} / \mathrm{dL})$, for which results were discarded. The dose selected for acarbose was $100 \mathrm{mg} / \mathrm{kg}$ b.w. because it had a similar effect as that observed with PEfAPSa at a dose of $50 \mathrm{mg} / \mathrm{kg}$ b.w. until the last hour of evaluation. The dose of $300 \mathrm{mg} / \mathrm{kg} \mathrm{b.w}$. did not generate hypoglycemia as seen in the toxicity assay in healthy mice, as shown in Figure 1A.

3.1.3. Evaluation of Acute Antihyperglycemic Activity of the Secondary Fractions (F2Sa, F5Sa, and F6Sa) of Salvia amarissima

Once the effect of PEfAPSa and acarbose were evaluated and adequate doses were selected, the extract was subjected to column chromatography, as described in Section 2, obtaining seven fractions named F1Sa, F2Sa, F3Sa, F4Sa, F5Sa, F6Sa, and F7Sa. These were evaluated to identify those that had antihyperglycemic activities similar to that of PEfAPSa. Figure 2 shows the fractions that had some antihyperglycemic activity. The fractions that showed activity were F2Sa, F5Sa, and F6Sa. F2Sa and F5Sa had activity at the first and third hours, respectively, but lost their activity after that time. F6Sa showed a reduction of blood glucose from the third hour and maintained its activity, similar to the case of PEfAPSa, and in the last two hours to the case of the acarbose control group. This fraction (F6Sa) was selected for later assays (Figure 1B).

\subsubsection{Acute Activity of F6Sa of Salvia amarissima}

After demonstrating the activity of F6Sa, it was evaluated at three different doses (25, 50 , and $100 \mathrm{mg} / \mathrm{kg} \mathrm{b.w.),} \mathrm{to} \mathrm{identify} \mathrm{which} \mathrm{of} \mathrm{these} \mathrm{had} \mathrm{better} \mathrm{antihyperglycemic} \mathrm{activity,}$ and the behavior of the fraction in STID mice. The single dose of F6Sa at $50 \mathrm{mg} / \mathrm{kg} \mathrm{b.w}$. (Figure 1C) induced a decrease in glycemia to almost $324 \mathrm{mg} / \mathrm{dL}, 5 \mathrm{~h}$ after administration, compared with the mice vehicle group $(386 \mathrm{mg} / \mathrm{dL})$, showing similar activity at the fifth hour to the acarbose control group ( $323 \mathrm{mg} / \mathrm{dL}$ ). Diabetic animals treated with F6Sa at doses of 25 and $100 \mathrm{mg} / \mathrm{kg}$ b.w. increased glycemic levels to $449 \mathrm{mg} / \mathrm{dL}$ and $428 \mathrm{mg} / \mathrm{dL}$, respectively, compared to the vehicle group. Because of these results, the selected dose was $50 \mathrm{mg} / \mathrm{kg}$ b.w. for later assays. As seen in Figure 1C, F6Sa showed similar behavior to the case in which there was no dose-dependent relationship between the evaluated doses. 


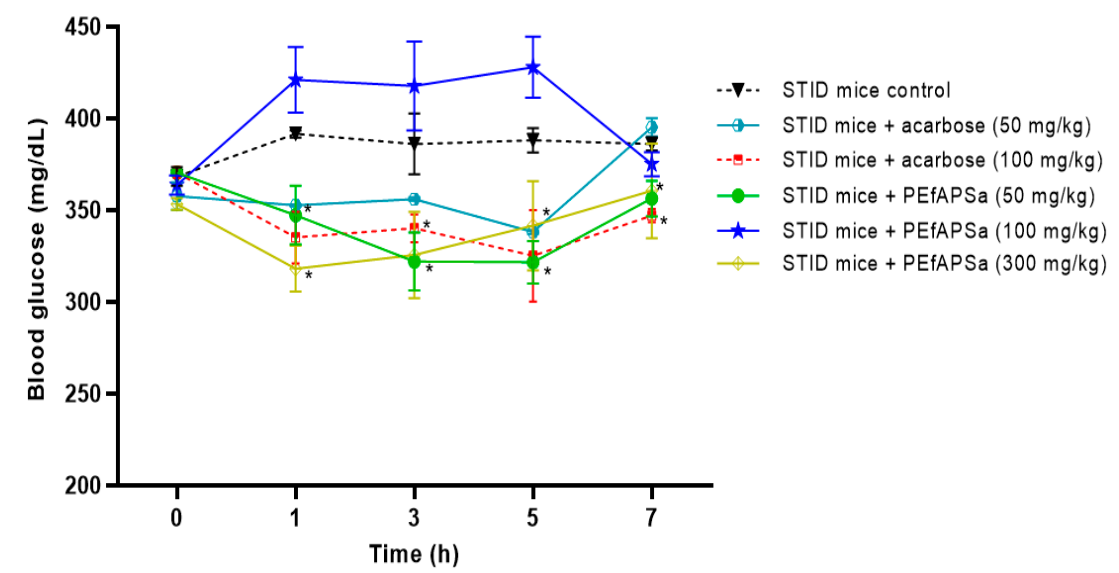

(A)

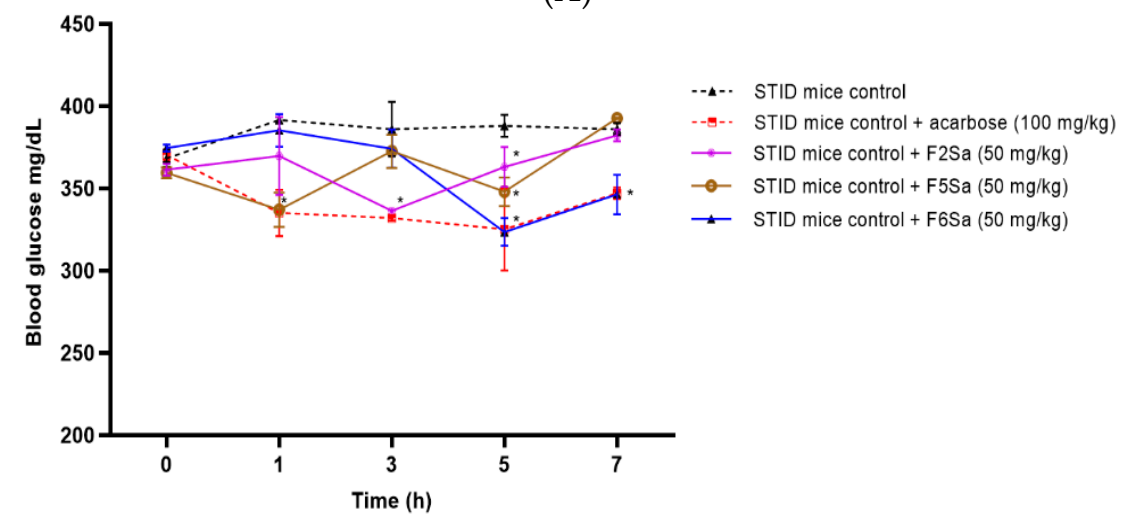

(B)

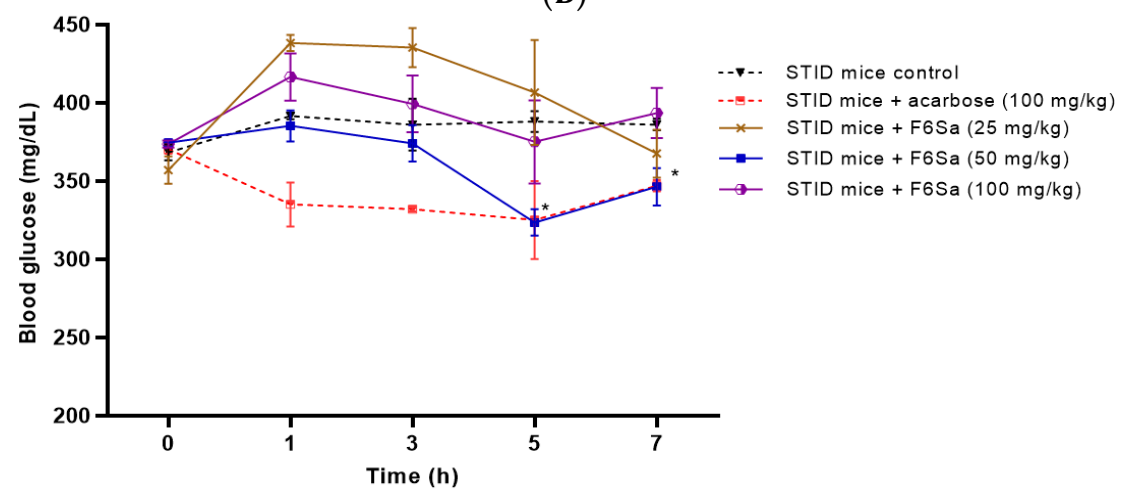

(C)

Figure 1. Acute assays of streptozocin-induced diabetic (STID) mice of (A) PEfAPSa in diabetic mice at doses of 50, 100, and $300 \mathrm{mg} / \mathrm{kg}$ b.w., and acarbose at doses of 50 and $100 \mathrm{mg} / \mathrm{kg}$ b.w.; (B) active fractions (F2Sa, F5Sa, and F6Sa) obtained from PEfAPSa, every fraction evaluated at the dose of $50 \mathrm{mg} / \mathrm{kg}$; (C) effect of Fraction 6 (F6Sa) in diabetic mice at doses of 25, 50, and $100 \mathrm{mg} / \mathrm{kg}$ b.w. Each point represents the mean $\pm \mathrm{SEM}, n=6 .{ }^{*} p<0.05$ represents significantly different two-way ANOVA followed by Dunnet's post hoc test for comparison with respect to STID mice control group at the same time.

\subsection{Subchronic Assay}

3.2.1. Organ Weight Measurement of PEfAPSa, F6Sa, and Acarbose on STID Mice of Subchronic Assay

As seen in Table 2, the analysis of the organs with the sub-chronic assay indicate that, with the exception of the spleen, differences exist between the diabetic control group and the diverse treatments. In the case of the liver in PEfAPSa and F6Sa, a diminution of the organ weight occurred, but this was similar to the healthy mice control, and in the 
macroscopic analysis there were no changes in the case of the STID mice liver, which had a pale color. PEfAPSa generated a reduction of the kidneys, but there was no relationship with the results shown in Figure 1C. Finally, for the results of the intestine, a significant increase in weight occurred in the diabetic control. This could be explained as a result of the polyphagia inherent with diabetes mellitus. PEfAPSa and F6Sa maintained similar values to that of the healthy control group. Finally, PEfAPSa and F6Sa generated a diminution of the intestine weight compared to the diabetic control group and the acarbose group and was also similar to the healthy group (Table 2).

Table 2. Relative organ weight of the sub-chronic assay PEfAPSa.

\begin{tabular}{|c|c|c|c|c|c|}
\hline \multicolumn{6}{|c|}{ Treatments } \\
\hline Organs & Healthy Mice & STID + Vehicle & $\begin{array}{l}\text { STID + PEfAPSa } \\
\text { (50 mg/kg b.w.) }\end{array}$ & $\begin{array}{c}\text { STID + F6Sa } \\
(50 \mathrm{mg} / \mathrm{kg} \mathrm{b.w.)}\end{array}$ & $\begin{array}{l}\text { STID + Acarbose } \\
\text { (100 mg/kg b.w.) }\end{array}$ \\
\hline Pancreas & $0.225 \pm 0.054$ & $0.121 \pm 0.056$ & $0.109 \pm 0.035$ & $0.111 \pm 0.060$ & $0.226 \pm 0.100$ \\
\hline Spleen & $0.085 \pm 0.016$ & $0.115 \pm 0.033$ & $0.089 \pm 0.005$ & $0.096 \pm 0.020$ & $0.093 \pm 0.032$ \\
\hline Stomach & $0.392 \pm 0.073$ & $0.227 \pm 0.032$ & $0.288 \pm 0.338$ & $0.136 \pm 0.084$ & $0.696 \pm 0.217^{*}$ \\
\hline Liver & $1.073 \pm 0.152$ & $1.592 \pm 0.183$ & $1.220 \pm 0.315^{*}$ & $0.638 \pm 0.587 *$ & $1.465 \pm 0.090$ \\
\hline Kidneys & $0.123 \pm 0.022$ & $0.430 \pm 0.035$ & $0.160 \pm 0.014$ * & $0.170 \pm 0.024$ * & $0.166 \pm 0.012 *$ \\
\hline Intestine & $1.487 \pm 0.051$ & $3.390 \pm 0.396$ & $1.838 \pm 0.842$ * & $0.824 \pm 1.445^{*}$ & $2.442 \pm 0.450$ * \\
\hline
\end{tabular}

Relative organ weight of the sub-chronic assay PEfAPSa, F6Sa, and acarbose on STID mice. Subchronic activity of PEfAPSa $50 \mathrm{mg} / \mathrm{kg}$ b.w., F6Sa $50 \mathrm{mg} / \mathrm{kg}$ b.w., and acarbose $100 \mathrm{mg} / \mathrm{kg}$ b.w. in STID mice. Each point represents the mean \pm SEM, $n=6$. ${ }^{*} p<0.05$ represents significantly different one-way ANOVA followed by Dunnet's post hoc test for comparison with respect to STID mice control of the respective organ. Relative organ weight was calculated as (organ weight (g)/body weight of animal on sacrifice day $(\mathrm{g})$ ) $\times 100$.

\subsubsection{Subchronic Assessment of Blood Glucose with PEfAPSa, F6Sa, and Acarbose on STID Mice}

Once the active doses of the diverse treatments of the acute assays were selected, the sub-chronic assay was performed. This test validated the STID mice model to measure different parameters that are altered in diabetes mellitus, such as glucose, HbA1c, TG, HDL, and organ alterations. In the case of validation of the diabetic model, the STID mice of the control group did not undergo a recovery, and glucose levels suggested that the development of experimental diabetes in animals was constant over time, with glycemia increasing from 347 to $471 \mathrm{mg} / \mathrm{dL}$ at the end of the experiment (Figure 2A). This is similar to poorly controlled diabetic patients. In contrast, the healthy vehicle group did not show an increase in blood glucose. The acarbose group showed constant glycemic levels (329 to $313 \mathrm{mg} / \mathrm{dL}$ ) in all of the assays. The PEfAPSa group showed major activity compared to the acarbose group, with a decrease from 323 to $262 \mathrm{mg} / \mathrm{dL}$. The F6Sa group showed major activity from the first week of treatment $(259 \mathrm{mg} / \mathrm{dL})$, maintaining glucose levels significantly lower than those of the control group at the end of the experimental period, and showed similar activity to the acarbose group (313 mg/dL). PEfAPSa and F6Sa showed better activity compared to the acarbose control group in the six weeks of treatment (Figure 2A).

3.2.3. Glycated Hemoglobin Measurement of PEfAPSa, F6Sa, and Acarbose on STID Mice of Subchronic Assay

The animals of the sub-chronic assay were also used for complementary analysis. $\mathrm{HbA} 1 \mathrm{c}$ was used in the complementary test to confirm and predict the degree of progression of the disease (Figure 2B). The evaluation of the $\mathrm{HbA} 1 \mathrm{c}$ for the sub-chronic assay indicated a partial relationship with the glucose level evaluation of previous results (Figure $2 \mathrm{~A}$ ). The healthy group maintained values from 4.5 to $5.3 \%$, whereas the diabetic group showed values of 7.6 to $9 \%$, and the acarbose, PEfAPSa, and F6Sa groups generated similar values, of between 7.3 to $7.5 \%$, as shown in Figure 2B. These results indicate that the evaluated treatments have similarities, as also seen in the results shown in Figure 2A,B. 
3.2.4. Measurement of Lipids Parameters in Subchronic Assay of PEfAPSa, F6Sa, and Acarbose on STID Mice

Other measured parameters that were found to have significant changes in diabetes mellitus were the TG and HDL. These parameters were also related in the metabolic syndrome and cardiovascular diseases [3]. The changes that generate S. amarissima in the lipid profile can serve to broaden the therapeutic uses of the plant. The variations observed in Figure 2C,D were measured in the sub-chronic assay.

Triglyceride Measurement of the Subchronic Assay of PEfAPSa, F6Sa, and Acarbose on STID Mice

The values obtained (Figure 2C) indicated that from the second week, all of the treatments showed a decrease in the values of TG. PEfAPSa and F6Sa maintained major activity for six weeks. They also maintained a lower concentration of this parameter and had a better effect than that observed with the acarbose group, which from the fourth week showed an increase in the TG values and at the end of the assay was similar to that of the STID mice group. This indicates that a reduction of the TG generates an improvement of diabetic management, decreasing the possibility of alterations in other parameters associated in a diabetic complex like dyslipidemias and/or cardiovascular complications, incorporating complementary activity for the use of the plant.

HDL Measurement of the Subchronic Assay of PEfAPSa, F6Sa, and Acarbose on STID Mice

The measured HDL values (Figure 2D) indicate that PEfAPSa and F6Sa, at the second week, increased the HDL values, followed by a similar decrease in the values for both cases. The combination of results could indicate an effective optimum control and reduction of cardiovascular disease associated with diabetes mellitus.

\subsection{Oral Tolerance Test Assays}

The principal mechanisms studied from the plants were focused on the inhibition of glucosidase enzymes and glucose transport mechanisms [7-12]. The $\alpha$-glucosidase enzymes mostly used for the evaluations of the glucosidase enzymes were sucrose and starch, and glucose was used for the glucose transporter, because the enzymes are focused on the degradation of disaccharides and polysaccharides. These tests were carried out to evaluate the activity of the different glucosidase enzymes (Figure 3A,B) and of the glucose transport (Figure 3C).

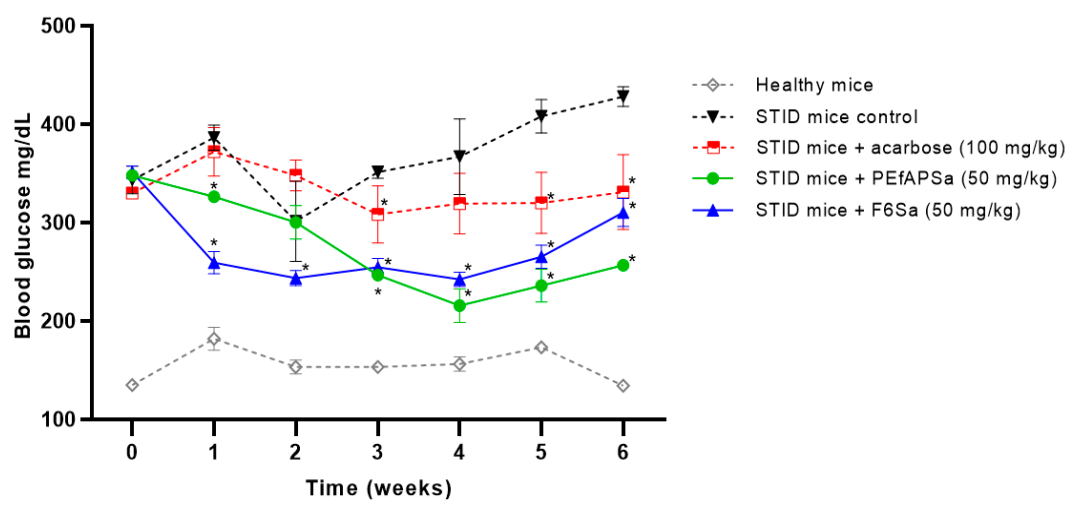

(A)

Figure 2. Cont. 


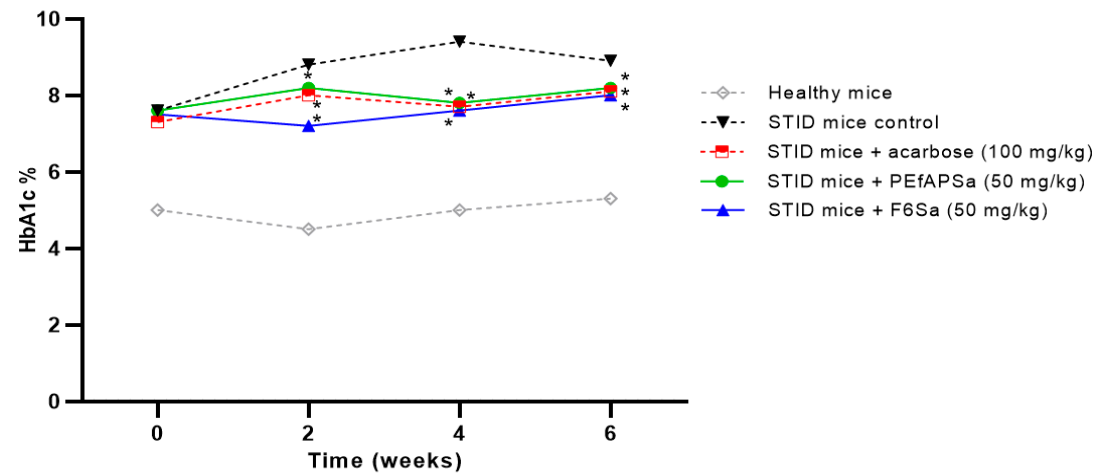

(B)

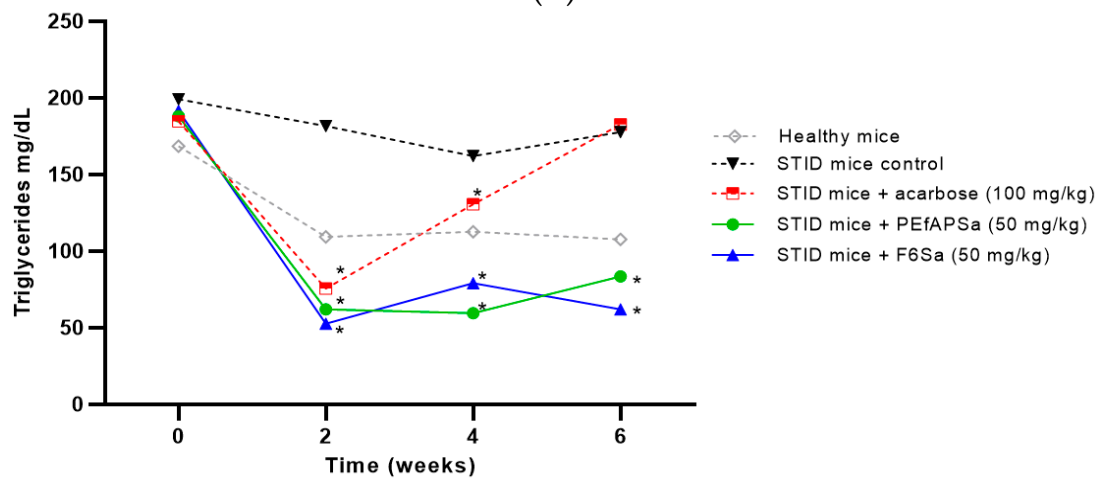

(C)

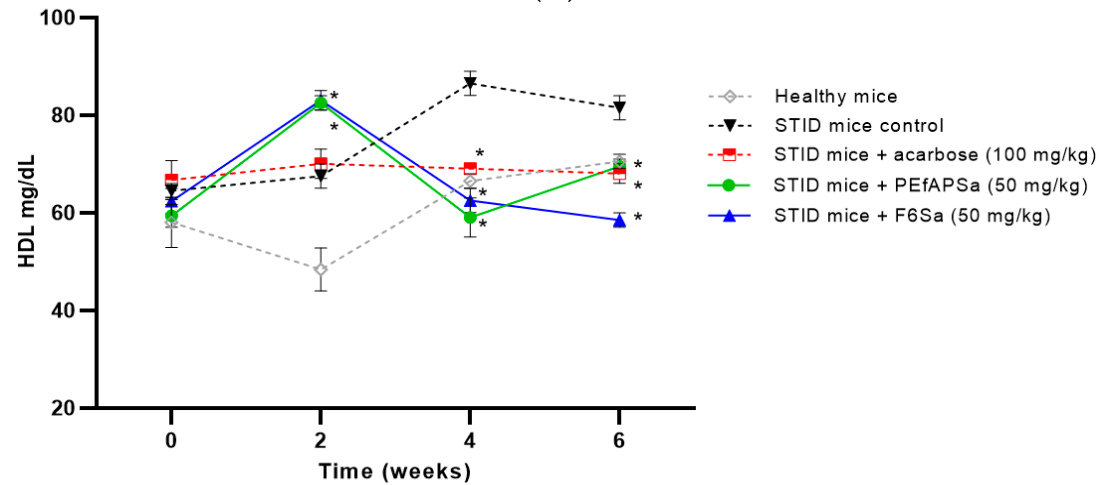

(D)

Figure 2. Subchronic assay results of the treatments: healthy mice, STID mice control group, STID mice + PEfAPSa $50 \mathrm{mg} / \mathrm{kg}$ b.w., STID mice + F6Sa $50 \mathrm{mg} / \mathrm{kg}$ b.w., and STID mice + acarbose $100 \mathrm{mg} / \mathrm{kg}$ b.w.; (A) glycemia in mg/dL, (B) HbA1c, (C) TG in mg/dL, and (D) HDL in mg/dL. Each point represents the mean $\pm \mathrm{SEM}, n=6{ }^{*} p<0.05$ represents significantly different two-way ANOVA followed by Dunnet's post hoc test for comparison with respect to STID mice control group at the same time and parameter measured.

\subsubsection{Oral Sucrose Tolerance Test (OSTT)}

In the OSTT (Figure 3A), the principal source of glucose is from the degradation of the disaccharide sucrose; the healthy control group in the assay maintained a blood glucose average of $100 \mathrm{mg} / \mathrm{dL}$, and the acarbose control group showed a decrease in glycemia to 81 $\mathrm{mg} / \mathrm{dL}$ in the first hour and then to $65 \mathrm{mg} / \mathrm{dL}$. The PEfAPSa did not induce a decrease in postprandial glycemia. Only F6Sa generated a diminution of the blood glucose levels that was similar to that of the healthy control group $(121 \mathrm{mg} / \mathrm{dL})$, as shown in Figure 3A. All of the treatments, with the exception of acarbose, returned to the values similar to those of the control group at the second hour. This indicates that part of the effect observed in acute and sub-chronic assays could be related to the inhibition of the hydrolysis of carbohydrates. 


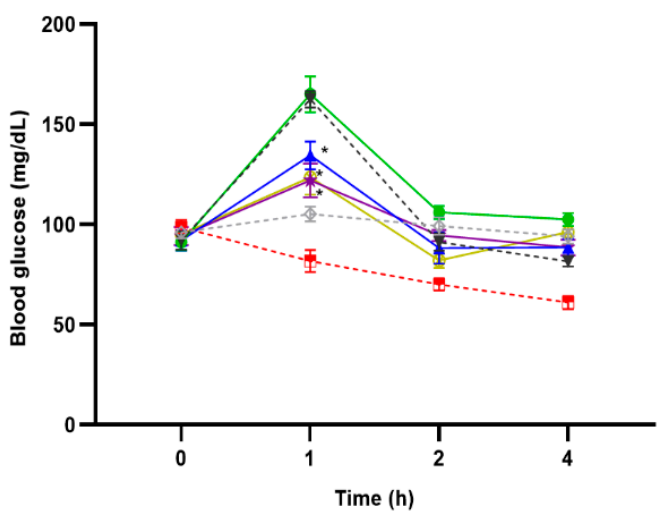

$\therefore \quad$ Healthy mice

$-\nabla$-. Healthy mice + sucrose control $(3 \mathrm{~g} / \mathrm{kg})$

-- Healthy mice + acarbose $(100 \mathrm{mg} / \mathrm{kg})$

$\rightarrow$ Healthy mice + PEfAPSa $(50 \mathrm{mg} / \mathrm{kg})$

\- Healthy mice + PEfAPSa $(100 \mathrm{mg} / \mathrm{kg})$

\# Healthy mice + F6Sa $(50 \mathrm{mg} / \mathrm{kg})$

-0 - Healthy mice + F6Sa $(100 \mathrm{mg} / \mathrm{kg})$

(A)

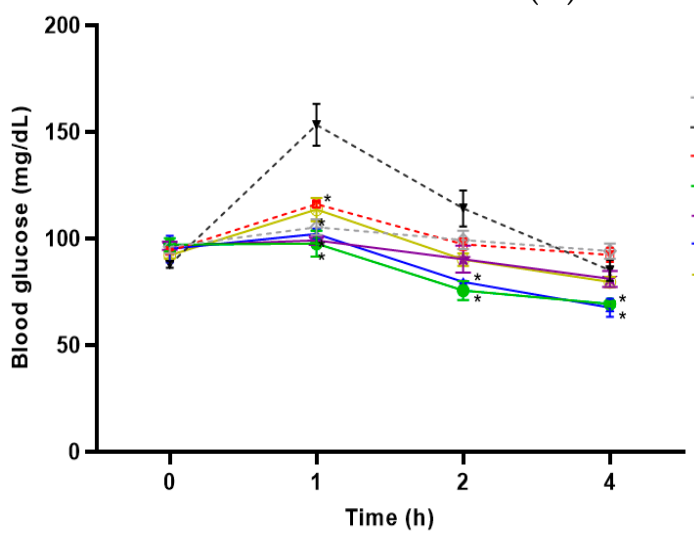

$\Leftrightarrow-$ Healthy mice

- - -. Healthy mice + starch $(3 \mathrm{~g} / \mathrm{kg})$

-.- Healthy mice + acarbose $(100 \mathrm{mg} / \mathrm{kg})$

- - Healthy mice + PEfSa $(50 \mathrm{mg} / \mathrm{kg}$ )

* Healthy mice + PEfSa $(100 \mathrm{mg} / \mathrm{kg})$

*- Healthy mice + F6Sa (50 mg/kg)

(2) Healthy mice + F6Sa $(100 \mathrm{mg} / \mathrm{kg})$

(B)

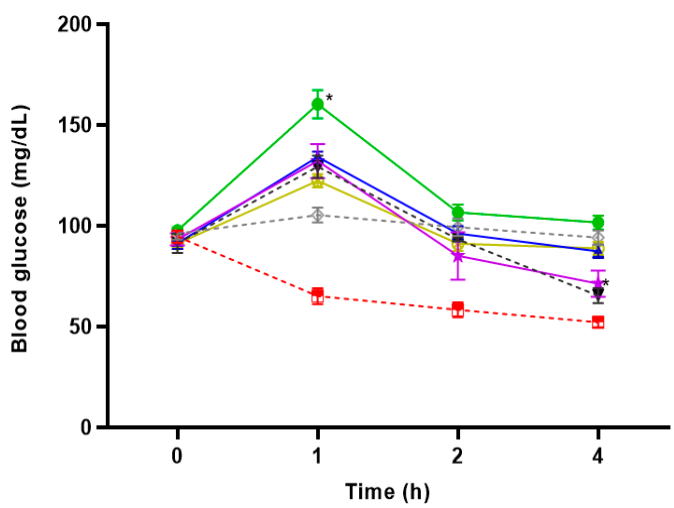

$\Leftrightarrow-$ Healthy mice

-.7.- Healthy mice + glucose $(1.5 \mathrm{~g} / \mathrm{kg})$

- - Healthy mice + canagliflozin $(100 \mathrm{mg} / \mathrm{kg})$

$\longrightarrow$ Healthy mice + PEfAPSa $(50 \mathrm{mg} / \mathrm{kg})$

\# Healthy mice + PEfAPSa $(100 \mathrm{mg} / \mathrm{kg})$

$\neg$ Healthy mice + F6Sa $(50 \mathrm{mg} / \mathrm{kg})$

- (2) Healthy mice + F6Sa $(100 \mathrm{mg} / \mathrm{kg})$

(C)

Figure 3. Oral tolerance test of healthy mice, PEfAPSa, at 50 and $100 \mathrm{mg} / \mathrm{kg}$ b.w., F6Sa at doses of 50 and $100 \mathrm{mg} / \mathrm{kg}$ b.w. in the subsequent carbohydrates. (A) Sucrose at a dose of $3 \mathrm{~g} / \mathrm{kg}$ b.w., and acarbose at a dose of $100 \mathrm{mg} / \mathrm{kg}$ b.w. (B) Starch at a dose of $3 \mathrm{~g} / \mathrm{kg}$ b.w. and acarbose at a dose of $100 \mathrm{mg} / \mathrm{kg}$ b.w. (C) Glucose at a dose of $1.5 \mathrm{~g} / \mathrm{kg}$ b.w. and canagliflozin at a dose of $100 \mathrm{mg} / \mathrm{kg}$ b.w. Each point represents the mean $\pm \mathrm{SEM}, n=6{ }^{*} p<0.05$ represents significantly different two-way ANOVA followed by Dunnet's post hoc test for comparison with respect to healthy control group with carbohydrate load at the same time.

\subsubsection{Oral Starch Tolerance Test (OStTT)}

In the case of the OStTT (Figure 3B), all of the treatments generated an inhibition of the glucose postprandial peak of the first hour after the starch loading, which was similar to the values of the acarbose group. The effects appeared to be more active at the doses of $50 \mathrm{mg} / \mathrm{kg}$ b.w. in both cases. The results suggest that if the carbohydrate is more complex, the activity of the treatment could be improved. 


\subsubsection{Oral Glucose Tolerance Test (OGTT)}

The results of the OGTT (Figure 3C) show that all of the evaluated treatments generated a reduction of the postprandial peak in comparison with the glucose group. Only PEfAPSa at $50 \mathrm{mg} / \mathrm{dL}$ generated an increase in blood glucose at the first hour with the dose of $50 \mathrm{mg} / \mathrm{kg}$ b.w. This indicated that the activity is not related to glucose transport.

\section{Discussion}

S. amarissima is a plant used in traditional Mexican medicine to treat DM. The background of the plant includes ethnomedical uses [21,23], and use in the evaluation of polar and medium polar extracts (MeOH:acetone and aqueose extracts), as well as in products obtained from these extracts (flavonoids and diterpens) [14,15,24-26]. The aforementioned studies focus on acute assays and some tolerances, while the present work provides information regarding acute, sub-chronic, and oral tolerance test assays of a non-polar extract and fraction. In addition, this study provides information regarding the behavior of $\mathrm{HbA} 1 \mathrm{c}$, TG, and HDL in a sub-chronic assay and information regarding the part of the mechanism through which they exert their effects.

The evaluation of the extract (PEfAPSa), according to acute toxic class method test 423 from the OECD guidelines [29], indicates that the estimated $\mathrm{LD}_{50}$ for the present study is determined as uncategorized because, at the maximum evaluated dose $(3000 \mathrm{mg} / \mathrm{kg}$ b.w.), this dosage causes no mortality. The information provided by this assay is useful for choosing the range of doses that can be used for an acute assay in STID with non-polar petroleum ether extract. These results are in accordance with those of another research group [24], who described the $\mathrm{LD}_{50}$ of an aqueous extract $(>5 \mathrm{~g} / \mathrm{kg})$. Additionally, in this experiment, the glycemia levels in the first $4 \mathrm{~h}$ of treatment indicated that no doses generated hypoglycemia, which is one of the side effects of the most common antidiabetic drugs [31].

The results of acute assays in STID mice, shown previously in Figure 1A-C, the model used in the assays conducted in this study, has been corroborated as a viable model for the evaluation of antidiabetic treatments where streptozotocin generates a disfunction in the pancreatic $\beta$-cells $[10,30,32-34]$. This work is focused on the evaluation of the non-polar petroleum ether extract (PEfAPSa) and its respective fractions, because studies focused on high-polarity compounds, such as flavonoids, or medium polarity compounds, such as diterpenes, possess antidiabetic activity, excluding the assessment of non-polar compounds [8-10]. In STID mice, single doses of petroleum ether extract (PEfAPSa) showed a diminution of glycemia at doses of 50 and $300 \mathrm{mg} / \mathrm{dL}$, and a dose of $50 \mathrm{mg} / \mathrm{dL}$ was selected as the optimal dose because, according to the results, it seems that a doseresponse relationship was not observed between them. Following analysis of PEfAPSa's antihyperglycemic effects, it was fractionated in a chromatographic silica gel column, and seven fractions were obtained, named F1Sa-F7Sa.

From the evaluated fractions, the fraction that maintained a similar activity to that of the extract was fraction 6 (F6Sa) in STID mice acute assays. From the three different evaluated doses, the selected dose was $50 \mathrm{mg} / \mathrm{kg}$ b.w., which showed antihyperglycemic activity at the fifth and seventh hours of treatment, being similar in time to PEfAPSa. This similarity is related to the presence of compounds that generate a glycemia reduction in STID mice, and these results show that the non-polar compounds obtained from petroleum ether extract can be as effective as polar and non-polar extracts, while fresh parts can be used in place of dry parts $[14,15,24-26]$. The benefit of the extended time effect in acute assays of PEfAPSa and F6Sa indicates that these treatments could be administrated less frequently throughout the day, while still being effective. Additionally, as seen in the PEfAPSa acute assay, the results of F6Sa indicate that there was no a dose-response relationship, an effect described as hormesis because the response was independent of the dose or because there was a biphasic dose-response relationship. To definitively confirm the presence of hormesis, it is necessary to evaluate more doses to generate a complete dose-response curve $[35,36]$. After the identification of the active fraction (F6Sa), it was 
subjected to preparative thin-layer chromatography, from which some products were identified. Three of these were preliminarily identified as terpene compounds, which could be inferred by their positive reaction to ceric sulphate, in which the color observed changed from purple to red. Plants of this family (Lamiaceae) contain a high quantity of terpenoids (monoterpenes, diterpenes, and triterpenes) [37-40], as in the case of $S$. amarissima, having been identified as neo-clerodane diterpenes, such as amarisolides, amarissinins, and teotihuacanine [24-26,38,41].

The diabetes mellitus 2 experimental model was suitable because glycemia levels were maintained above $350 \mathrm{mg} / \mathrm{dL}$ [31,34], generating similar biochemical changes to diabetes in humans (glycemia and HbA1c) [31]. The evaluation of the effects in the sub-chronic assay, using the previously selected doses, indicated that PEfAPSa and F6Sa showed higher activity than the control (acarbose) during the time of the assay. Our evaluation of $\mathrm{HbA1c}$ suggests that PEfAPSa and F6Sa have similar effects to the acarbose control group, with the three groups showing similar assay results, as shown by the effects below. The similarity with acarbose indicates that products with activity over $\alpha$-glucosidase enzymes could exist, therefore affecting the $\mathrm{HbA1c}$ levels [3].

DM2 is characterized by relative insulin deficiency and a decrease in lipoprotein due to a decrease in adiponectin, resulting in high levels of low-density lipoprotein and TG and low levels of HDL. As reported in Kidwai [3], a relationship exists between high levels of $\mathrm{HbA} 1 \mathrm{c}$ and dyslipidemia; HbA1c increases the risk of hypertriglyceridemia by $2.69 \%$ [3] as well as the development of a high risk of cardiovascular disease. As seen with PEfAPSa and F6Sa, the reduction in glycemia in acute and sub-chronic assays, TG, and maintenance of $\mathrm{HbA1c}$, suggest that these two therapies are viable treatments for diabetes mellitus and for the control of $\mathrm{HbA1c}$ values, avoiding its increase and for TG and HDL taking them closer to healthy mice values than diabetic animals.

The OTT was used to determine the treatments' potential mechanisms of action. These assays are focused on various glucosidase enzymes for a specific kind of bond $(\alpha-$ glycosidic bond), and on glucose transport. As seen in previous results, the OGTT showed that the effects of the extract, fraction, and compounds are not related to the glucose transport because there were no changes in the glucose postprandial peak in the first hour. Furthermore, in the case of sucrose and starch, PEfAPSa and F6Sa inhibit the postprandial glucose peak, whereby the action of the treatments is focused on these enzymes ( $\alpha 1-2$ for sucrose and mixtures of $\alpha 1-4$ and $\alpha 1-6$ for starch), which is congruent with the previous results. These effects, in part, could be explained because the enzymes have significant permeability in the small intestine, which makes it possible for them to travel through the intestine or to another part of the body [42-46]. This explains how PEfAPSa and F6Sa can maintain the levels of hemoglobin in sub-chronic assays, reducing the levels of glucose obtained from the diet.

\section{Conclusions}

PEfAPSa and F6Sa showed activity in acute and sub-chronic assays of STID mice and in the regulation of the levels of blood glucose in the acute assay and $\mathrm{HbA} 1 \mathrm{c}$ in the sub-chronic assay. Lipid parameters indicate that these could be effective complementary treatments for dyslipidemias associated with DM.

In the OTT, the activity is focused on sucrose and starch enzymes, and does not involve glucose transport. This indicates that the combination of secondary metabolites contained in the extract and the fraction are responsible for the antihyperglycemic activity in acute and long administration periods. Futures studies will evaluate different terpenic compounds and combinations of those products to find the best mix for a better treatment.

Author Contributions: Conceptualization, J.I.S.-P. and F.C.; methodology, J.I.S.-P., G.C., C.V., E.B., and F.C.; validation and formal analysis, J.I.S.-P., C.V., E.B., and F.C.; investigation, J.I.S.-P.; resources, G.C. and F.C.; writing-original draft preparation, J.I.S.-P.; supervision, G.C. and F.C.; project administration, G.C. and F.C.; funding acquisition, G.C. and F.C. All authors have read and agreed to the published version of the manuscript. 
Funding: The research was supported by grants from Instituto Mexicano del Seguro Social (IMSS): FIS/IMSS/PROT/PRIO/19/110 and FIS/IMSS/PROT/G17-2/1722 awarded to F.C.

Institutional Review Board Statement: The study was conducted according to the guidelines of the Declaration of Helsinki, and in accordance with the regulations of the relevant clinical research ethics approved by the Local Ethics Committee of the Instituto Mexicano del Seguro Social, protocol codes R-2019-3601-227 (01-August-2019) and R-2019-3601-004 (01-January-2019).

Informed Consent Statement: Not applicable.

Data Availability Statement: The data presented in this study are available on request from the corresponding author.

Acknowledgments: This work is taken in part from the Ph.D. thesis of Jesus Ivan Solares Pascasio. We would like to thank the National Council of Science and Technology for the scholarship (455972), and contract grant sponsor FIS/IMSS/PROT/PRIO/19/110 and Gabriel Alfonso Gutiérrez-Rebolledo.

Conflicts of Interest: The authors declare no conflict of interest.

Sample Availability: Not available.

\section{References}

1. WHO: World Health Organization. Informe Mundial Sobre la Diabetes, Resumen de Orientación. Available online: https:/ /apps.who.int/iris/bitstream/handle/10665/204877/WHO_NMH_NVI_16.3_spa.pdf;jsessionid=D89B7AA6513AE700 A7ECC662D47C5EEE?sequence=1 (accessed on 15 August 2020).

2. IDF, Diabetes Atlas 2017, 9th Edition. Available online: https://www.diabetesatlas.org/ (accessed on 15 August 2020).

3. Kidwai, S.S.; Nageen, A.; Bashir, F.; Ara, J. HbA1c-A predictor of dyslipidemia in type 2 diabetes mellitus. Pak. J. Med. Sci. 2020, 36, 1339-1343. [CrossRef] [PubMed]

4. INEGI Instituto Nacional de Geografía y Estadística Comunicado de Prensa. Available online: https://www.inegi.org.mx/ contenidos/saladeprensa/boletines/2018/EstSociodemo/DEFUNCIONES2017.pdf (accessed on 15 August 2020).

5. Zárate, A.; Islas, S.; Saucedo, R. Eficacia y efectos adversos de los antidiabéticos orales. Gac. Med. Mex. 2014, 150, 5-7. [PubMed]

6. Tran, L.; Zielinski, A.; Roach, A.H.; Jende, J.A.; Householder, A.M.; Cole, E.E.; Atway, S.A.; Amornyard, M.; Accursi, M.L.; Shieh, S.W.; et al. The Pharmacologic Treatment of Type 2 Diabetes: Oral Medications. Ann. Pharmacother. 2015, 119, 1-17. [CrossRef] [PubMed]

7. World Health Organization (WHO). Programme on Tradicional Medicine Regulatory Situation of Herbal Medicines-A Worldwide Review; World Health Organization. 1998. Available online: http://apps.who.int/iris/handle/10665/63801 (accessed on 17 August 2019).

8. Mata, R.; Cristians, S.; Escandón-Rivera, S.; Juárez-Reyes, K.; Rivero-Cruz, I. Mexican antidiabetic herbs: Valuable sources of inhibitors of $\alpha$-glucosidases. J. Nat. Prod. 2013, 76, 468-483. [CrossRef] [PubMed]

9. Escandón-Rivera, S.; Pérez-Vásquez, A.; Navarrete, A.; Hernández, M.; Linares, E.; Bye, R.; Mata, R. Anti-hyperglycemic activity of major compounds from Calea ternifolia. Molecules 2017, 22, 289. [CrossRef] [PubMed]

10. Calzada, F.; Solares-Pascasio, J.; Ordoñez-Razo, R.; Velazquez, C.; Barbosa, E.; García-Hernández, N.; Mendez-Luna, D.; CorreaBasurto, J. Antihyperglycemic activity of the leaves from Annona cherimola miller and rutin on alloxan-induced diabetic rats. Pharmacogn. Res. 2017, 9, 1. [CrossRef] [PubMed]

11. Li, K.; Yao, F.; Xue, Q.; Fan, H.; Yang, L.; Li, X.; Sun, L.; Liu, Y. Inhibitory effects against $\alpha$-glucosidase and $\alpha$-amylase of the flavonoids-rich extract from Scutellaria baicalensis shoots and interpretation of structure-activity relationship of its eight flavonoids by a refined assign-score method. Chem. Cent. J. 2018, 12. [CrossRef]

12. Martínez, A.L.; Madariaga-Mazón, A.; Rivero-Cruz, I.; Bye, R.; Mata, R. Antidiabetic and Antihyperalgesic Effects of a Decoction and Compounds from Acourtia thurberi. Planta Med. 2017, 83, 534-544. [CrossRef]

13. Chávez-Silva, F.; Cerón-Romero, L.; Arias-Durán, L.; Navarrete-Vázquez, G.; Almanza-Pérez, J.; Román-Ramos, R.; RamírezÁvila, G.; Perea-Arango, I.; Villalobos-Molina, R.; Estrada-Soto, S. Antidiabetic effect of Achillea millefollium through multitarget interactions: $\alpha$-glucosidases inhibition, insulin sensitization and insulin secretagogue activities. J. Ethnopharmacol. 2018, $212,1-7$. [CrossRef]

14. Salinas-Arellano, E.; Pérez-Vásquez, A.; Rivero-Cruz, I.; Torres-Colin, R.; González-Andrade, M.; Rangel-Grimaldo, M.; Mata, R. Flavonoids and Terpenoids with PTP-1B Inhibitory Properties from the Infusion of Salvia amarissima Ortega. Molecules 2020, 25, 3530. [CrossRef]

15. Mata, R.; Figueroa, M.; Navarrete, A.; Rivero-Cruz, I. Chemistry and Biology of Selected Mexican Medicinal Plants. Prog. Chem. Org. Nat. Prod. 2019, 108, 1-142. [CrossRef]

16. Calzada, F.; Bautista, E.; Barbosa, E.; Salazar-Olivo, L.A.; Alvidrez-Armendáriz, E.; Yepez-Mulia, L. Antiprotozoal Activity of Secondary Metabolites from Salvia circinata. Rev. Bras. Farmacogn. 2020, 30, 593-596. [CrossRef]

17. Calzada, F.; Bautista, E. Plants used for the treatment of diarrhoea from Mexican flora with amoebicidal and giadicidal activity, and their phytochemical constituents. J. Ethnopharmacol. 2020, 253, 112676. [CrossRef] [PubMed] 
18. Kumar, V.; Sachan, R.; Rahman, M.; Sharma, K.; Al-Abbasi, F.A.; Anwar, F. Prunus amygdalus extract exert antidiabetic effect via inhibition of DPP-IV: In-silico and in-vivo approaches. J. Biomol. Struct. Dyn. 2020, 1-15. [CrossRef] [PubMed]

19. Lankatillake, C.; Huynh, T.; Dias, D.A. Understanding glycaemic control and current approaches for screening antidiabetic natural products from evidence-based medicinal plants. Plant Methods 2019, 15, 1-35. [CrossRef]

20. Rey, D.; Miranda Sulis, P.; Alves Fernandes, T.; Gonçalves, R.; Silva Frederico, M.J.; Costa, G.M.; Aragon, M.; Ospina, L.F.; Mena Barreto Silva, F.R. Astragalin augments basal calcium influx and insulin secretion in rat pancreatic islets. Cell Calcium 2019, 80 56-62. [CrossRef]

21. Castro Juarez, C.J.; Villa Ruano, N.; Ramirez García, S.A.; Mosso Gonzalez, C. Uso medicinal de plantas antidiabéticas en el legado etnobotánico oaxaqueño. Rev. Cuba. Plantas Med. 2014, 19, 101-120. Available online: http:/ /scielo.sld.cu/scielo.php? script=sci_arttext\&pid=S1028-47962014000100012\&lng=es\&tlng=es (accessed on 17 August 2020).

22. Andrade-Cetto, A.; Heinrich, M. Mexican plants with hypoglycaemic effect used in the treatment of diabetes. J. Ethnopharmacol. 2005, 99, 325-348. [CrossRef]

23. López Ferrer, C.E.; Sánchez Dirzo, G.; Arrieta Baez, D.; Román García, J.H. Estudio preliminar fitoquímico y de la actividad antimicrobiana de Salvia amarissima Ort. Investig. Univ. Multidiscip. Rev. Investig. Univ. Simón Bolívar 2010, 9, 7. Available online: http:/ / dialnet.unirioja.es / servlet/articulo?codigo=3705814\&info=resumen\&idioma=ENG (accessed on 17 August 2020).

24. Flores-Bocanegra, L.; González-Andrade, M.; Bye, R.; Linares, E.; Mata, R. $\alpha$-Glucosidase Inhibitors from Salvia circinata. J. Nat. Prod. 2017, 80, 1584-1593. [CrossRef]

25. Bautista, E.; Fragoso-Serrano, M.; Ortiz-Pastrana, N.; Toscano, R.A.; Ortega, A. Structural elucidation and evaluation of multidrugresistance modulatory capability of amarissinins A-C, diterpenes derived from Salvia amarissima. Fitoterapia 2016, 114, 1-6. [CrossRef]

26. Bautista, E.; Fragoso-Serrano, M.; Toscano, R.A.; García-Peña, M.D.R.; Ortega, A. Teotihuacanin, a Diterpene with an Unusual Spiro-10/6 System from Salvia amarissima with Potent Modulatory Activity of Multidrug Resistance in Cancer Cells. Org. Lett. 2015, 17, 3280-3282. [CrossRef]

27. Valdés, M.; Calzada, F.; Mendieta-Wejebe, J.E.; Merlín-Lucas, V.; Velázquez, C.; Barbosa, E. Antihyperglycemic effects of Annona diversifolia safford and its acyclic terpenoids: $\alpha$-glucosidase and selective SGLT1 inhibitiors. Molecules 2020, 25, 3361. [CrossRef]

28. NOM-062-ZOO-1999. Norma Oficial Mexicana NOM-062-ZOO-1999: Especificaciones técnicas Para la Producción, Cuidado y uso de los Animales de Laboratorio. Available online: http:/ / publico.senasica.gob.mx/?doc=743 (accessed on 15 August 2020).

29. Organisation for Economic Co-operation and Development. Test No. 423: Acute Oral toxicity-Acute Toxic Class Method. In OECD Guidelines for the Testing of Chemicals, Section 4; OECD Publishing: Paris, France, 2002. [CrossRef]

30. Porwal, M.; Khan, N.A.; Maheshwari, K.K. Evaluation of acute and subacute oral toxicity induced by ethanolic extract of Marsdenia tenacissima leaves in experimental rats. Sci. Pharm. 2017, 85, 29. [CrossRef] [PubMed]

31. Grunberger, G. Should Side Effects Influence the Selection of Antidiabetic Therapies in Type 2 Diabetes? Curr. Diab. Rep. 2017, 17. [CrossRef]

32. Katisart, T.; Konsue, A. Acute toxicity of flower extracts from Dolichandrone serrulata in mice. Phcog. Res. 2019, 11, 230-235. Available online: https:/ / www.phcogres.com/text.asp?2019/11/3/230/265056 (accessed on 17 August 2020). [CrossRef]

33. Diab, R.A.H.; Fares, H.; Abedi-Valugerdi, M.; Kumagai-Braesch, M.; Holgersson, J.; Hassan, M. Immunotoxicological Effects of Streptozotocin and Alloxan: In Vitro and In Vivo Studies. Immunol. Lett. 2015, 163, 193-198. [CrossRef] [PubMed]

34. Andrade-Cetto, A.; Becerra-Jiménez, J.; Cárdenas-Vázquez, R. Alfa-glucosidase-inhibiting activity of some Mexican plants used in the treatment of type 2 diabetes. J. Ethnopharmacol. 2008, 116, 27-32. [CrossRef] [PubMed]

35. López-Diazguerrero, N.E.; Yazmín, V.; Puertos, G.; Hernández-Bautista, R.J.; Alarcón-Aguilar, A.; Luna-López, A.; Fainstein, M.K.; Königsberg, M. Hormesis: Lo que no mata, fortalece. Gac. Med. Mex. 2013, 149, 438-447. Available online: https: //www.anmm.org.mx/GMM/2013/n4/GMM_149_2013_4_438-447.pdf (accessed on 17 August 2020).

36. Calabrese, E.J.; Calabrese, V.; Giordano, J. The role of hormesis in the functional performance and protection of neural systems. Brain Circ. 2017, 3, 1-13. [CrossRef] [PubMed]

37. Ghosh, S.; Rangan, L. Molecular Docking and Inhibition Kinetics of $\alpha$-glucosidase Activity by Labdane Diterpenes Isolated from Tora Seeds (Alpinia nigra B.L. Burtt.). Appl. Biochem. Biotechnol. 2014, 175, 1477-1489. [CrossRef]

38. Fragoso-serrano, M.; Ortiz-pastrana, N.; Luna-cruz, N.; Toscano, R.A.; Alpuche-Solís, A.G.; Ortega, A.; Bautista, E. Amarisolide F, an Acylated Diterpenoid Glucoside and Related Terpenoids from Salvia Amarissima. J. Nat. Prod. 2018, 82, 631-635. [CrossRef]

39. Montesino, N.L.; Schmidt, T.J. Salvia species as sources of natural products with antiprotozoal activity. Int. J. Mol. Sci. 2018, 19, 264. [CrossRef] [PubMed]

40. Wu, Y.B.; Ni, Z.Y.; Shi, Q.W.; Dong, M.; Kiyota, H.; Gu, Y.C.; Cong, B. Constituents from salvia species and their biological activities. Chem. Rev. 2012, 112, 5967-6026. [CrossRef] [PubMed]

41. Maldonado, E.; Cárdenas, J.; Bojórquez, H.; Escamilla, E.M.; Ortega, A. Amarisolide, a neo-clerodane diterpene glycoside from Salvia amarissima. Phytochemistry 1996, 42, 1105-1108. [CrossRef]

42. Karakaya, S.; Gözcü, S.; Güvenalp, Z.; Özbek, H.; Yuca, H.; Dursunoğlu, B.; Kazaz, C.; Kılıç, C.S. The $\alpha$-amylase and $\alpha$-glucosidase inhibitory activities of the dichloromethane extracts and constituents of Ferulago bracteata roots. Pharm. Biol. 2018, 56, 18-24. [CrossRef] [PubMed]

43. Ding, H.; Hu, X.; Xu, X.; Zhang, G.; Gong, D. Inhibitory mechanism of two allosteric inhibitors, oleanolic acid and ursolic acid on

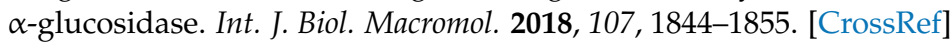


44. Cogollo Carvajal, A.M.; Restrepo Múnera, L.M.; Ruiz Correa, A.M. Caracterización de diferentes cepas de células Caco-2 para su uso en ensayos de permeabilidad in vitro. Rev. Cuba. Farm. 2016, 50, 1-9. Available online: http://revfarmacia.sld.cu/index.php/ $\mathrm{far} / \mathrm{rt} /$ printerFriendly/38/42 (accessed on 19 August 2020).

45. Yee, S.W. In vitro permeability across Caco-2 cells (Colonic) can predict in vivo absorption in man-Fact or myth. Pharm. Res. 1997, 36, 763-766. Available online: https:/ /link.springer.com/article/10.1023/A:1012102522787 (accessed on 19 August 2020). [CrossRef]

46. Wang, X.X.; Liu, G.Y.; Yang, Y.F.; Wu, X.W.; Xu, W.; Yang, X.W. Intestinal Absorption of Triterpenoids and Flavonoids from Glycyrrhizae radix et rhizoma in the Human Caco-2 Monolayer Cell Model. Molecules 2017, 22, 1627. [CrossRef] 